In Memoriam / Luis González Catalán

1946-2020

Pp. 11 a 12

\title{
IN MEMORIAM \\ LUIS GONZÁLEZ CATALÁN \\ 1946-2020
}

\author{
Miguel Castillo Didier \\ Universidad de Chile \\ Chile
}

En verdad, se puede caracterizar al Maestro Luis González como un verdadero héroe de la música, un verdadero héroe de la música de órgano y de todo el inmenso tesoro de la música sagrada, tan dejada mano por la Iglesia Católica, aquí, en Chile, y, en general, en América Latina. En efecto, su intensa y apasionada actividad en ese campo de la música bien puede calificarse de heroica. Incansablemente estudió, enseñó, tocó, compuso, organizó y dirigió coros. Y toda su inmensa labor no la realizó en un ambiente propicio, sino haciendo frente a obstáculos, dificultades y no pocas incomprensiones.

El Maestro Luis González nació en Santiago el 29 de Agosto de 1946. Su amor por la música se manifestó desde su más tierna edad. Ya con conocimientos de piano, cuando el Conservatorio Nacional contrató al malogrado Pedro Deckers como profesor de órgano, en 1968, Luis González tomó clases particulares con él, las que se vieron interrumpidas por la trágica muerte del sacerdote. Pero continuó sus estudios en la Escuela Moderna de Música. En 1970 viajó a Estados Unidos donde siguió una licenciatura en órgano en la Texas Tech University y fue alumno del profesor Judson Maynard. Dos años después, en 1972, obtuvo una beca del gobierno de Francia para estudiar organería en los talleres de Maison Danion-González, en París, trabajo que continuó posteriormente en los Talleres Koenig, en Alsacia. Su estadía en Francia le permitió perfeccionar sus estudios de órgano y de improvisación con dos grandes maestros franceses del siglo XX Jean Langlais y André Isoir.

Sus estudios académicos regulares culminaron con su graduación como Licenciado en Artes Musicales en diciembre de 1995, luego como Magíster en Artes Musicales, y, finalmente, el 10 de agosto de 2013 recibió en Título de Doctor en Filosofía, mención Bellas Artes, como alumno del Dr. Roy Wilson. 
$\mathrm{Su}$ incansable labor en Chile como ejecutante y como restaurador de numerosos instrumentos es difícil de trazar en corto espacio. La cantidad de conciertos que dio a través de los años es incalculable. Puede considerarse una hazaña el haber presentado las obras completas para órgano de Juan Sebastián Bach, Carl Ph. E. Bach, Dietrich Buxtehude, Johann L. Krebs, Félix Mendelssohn. Sólo la "Antología de Música Organística" fue ejecutada en 42 conciertos en 1982. Entre los conciertos especiales que dio, merece recordarse el dedicado a las Mujeres Organistas en el que pudimos escuchar obras de Fanny Mendelssohn y de Clara Schumann, entre otras compositoras.

Fuera de Chile, el Maestro tuvo oportunidad de mostrar su arte en diversos países: Alemania, Argentina, Brasil, Colombia, Costa Rica, Ecuador, Francia, México, Paraguay, Suiza y Uruguay.

Fue un honor, sin duda muy gratificante para él, el tocar la Misa de Acción de Gracias en la Basílica de San Pedro en Roma para la Canonización de Santa Teresa de Jesús de Los Andes.

Su labor de rescate de instrumentos fue inmensa. Recordemos siquiera los órganos de San Ignacio; de Santa Ana; el de San Agustín; el que trasladó a la Iglesia de los Benedictinos; el órgano Debierre de la Catedral de La Serena, por décadas abandonado; el de la Parroquia de Agua Santa en Viña. Éstos y muchísimos otros fueron devueltos a la vida sonora por el trabajo del Maestro Luis González.

Pese al casi total abandono del tesoro de la música sagrada por la Iglesia Católica de Chile, Luis González pudo ser organista litúrgico. Tocó durante muchos años misas en diversas iglesias, corriendo, literalmente, de un templo a otro.

Su labor como compositor se centró en la música sagrada. Sus múltiples trabajos como ejecutantes y como organero no le dejó tiempo para la creación musical. Compuso cuatro Misas tres, un Te Deum, muchos himnos para la Liturgia de las Horas, y el Oficio Divino completo de la Fiesta de Santa Teresa de Jesús de Los Andes y la de otros santos. También compuso un Tema con Variaciones, tres Tríos para Flauta, Fagot y Piano, un Pater Noster para Barítono y órgano o cuarteto de cuerdas. y las siguientes obras para órgano: 1) A Toccata You've never heard, 2) Fantasía, Coral y Passacaglia sobre el coral de la Pasión, 3) Impro for Cedrik, y 4) Suite para Órgano y Marimba.

Umbra et pulvis non factus est. In luce operis eius manet.

No se ha vuelto sombra y polvo. Permanece en la luz de su obra.

Miguel Castillo Didier 